\title{
Comparison of Mechanical Properties of Aluminium - Boron Carbide at Micron and Nanometer Size Grain Particles using Powder Metallurgy
}

\author{
Mohd Adnan \\ Department of Mechanical Engineering \\ G.R.D. Institute of Management and Technology, \\ 214 Rajpur road. Dehradun,
}

\author{
Vinod Kumar \\ Department of Mechanical Engineering \\ G.R.D. Institute of Management and Technology, \\ 214 Rajpur road. Dehradun,
}

\begin{abstract}
Metal matrix composites (MMCs) are emerging as latest engineering materials due to their strength, ductility and hardness. The Al matrix can be improvised by reinforcing with other hard ceramics particles like $\mathrm{SiC}, \mathrm{Al}_{2} \mathrm{O}_{3}, \mathrm{~B}_{4} \mathrm{C}$ etc. In the present a comparative study, is done between particle of MMCs at micron and nanometer level. To compare the hardness and tensile strength of MMCs are prepared by reinforcing Al matrix with $\mathrm{B}_{4} \mathrm{C}$ particles. By powder metallurgy, aluminium matrix 50 micron and 50 nanometer particles was reinforced with boron carbide particles of 50 micron and 50 nanometer particle sizes respectively. Different samples are prepared by varied the wt \% of $\mathrm{B}_{4} \mathrm{C}$ with $3,6,9,12$ and $15 \mathrm{wt} \%$ at both micron and nanometer level. The mechanical properties of the formed AMCs are investigated. Material properties like ultimate tensile strength, and hardness of newly developed metal matrix composites is improved significantly by incorporating boron carbide particles. And tensile strength and hardness was found to increase by decreasing the particle size and also with the increase in wt\% of the reinforcement. At same material ratio there mechanical properties are increased by decreasing the size of particles.
\end{abstract}

Keywords: Boron Carbide, Matrix, MMCs, Reinforcement, AMCs.

\section{INTRODUCTION}

$\mathrm{s}$ the global competition increases day by day, industries like automobile and aviation are anticipated to invent new materials having light weight along with enhances hardness and strength.[1]After iron, aluminium is the second most widely used material in the world.[2] When materials like Sic, $\mathrm{Al}_{2} \mathrm{O}_{3}$, and $\mathrm{B}_{4} \mathrm{C}$ are reinforced it strengthened aluminum[3].

Boron Carbide is the third hardest substance, it also have others properties like low specific gravity, high elastic modulus value and neutron absorption, which help $\mathrm{B}_{4} \mathrm{C}$ to be widely used as cermets and armor materials. [4]

Based on the type of reinforcement, size and morphology, the AMCs are fabricated by different methods such as stir casting, squeeze casting, spray deposition, liquid infiltration, and powder metallurgy.[4]-[7].Powder Metallurgy processing is an effective method to manufacture MMCs with high, medium and low volume of reinforcement with fairly uniform distribution. Powder metallurgy die to produce weakly cohesive (cold welding) very near the dimensions of the object ultimately to be manufactured. Pressures of 1-15 tons are generally used to compact the metal powder and form green part. Then subsequent heating or sintering is done of green part in the mould with temperature below melting point under non oxidizing atmosphere[4].

K.K. Saravanan, S Mahendran, (2020)[8] article deals with aluminium 6082 alloy is mixed with boron carbide reinforced material by mechanical stirring method The specimen is tested by hardness and tensile test. The SEM analysis is made and calculates the grain particle distribution. These casting is machined in CNC machines. The machining parameters speed, feed, depth of cut and all type of inserts are studied. These machinability studies are compared with mono alloy and composite materials. The machinability values are higher for composite material than monolithic alloy. The novelty of this project is to investigate the mechanical properties of aluminium 6082 with various weight percentages of boron carbide materials. Chander Prakash, Sunpreet Singh, Shubham Sharma, Harish Garg, Jujhar Singh, Harish Kumar, Gursharan Singh. (2020)[7] research aim to fabricate Al with carbon nano tube and silicon carbide particle to form hybrid nano composite by alloying aluminium (Al), Carbon nano tube and silicon carbide powder to homogenous powder of element and after that spark plasma sintering is used to sintering the mixture. Mechanical properties and microstructural characteristics are analyzed to see the effect of carbon nano tube weight percentage (1\%, 3\% and 5\%) and silicon carbide particle as reinforcement. Further Fieldemission scanning electron microscopy, energy-dispersion $\mathrm{X}$-ray spectroscopy optical microscope is used to investigate the surface topography and microstructure. Hardness of the specimen is measured by using Vickers hardness tester

Scanning electron microscopy (SEM) and microstructure micrographs show that the sintered Al-CNTs-SiCp 
composite having quality reinforcement of CNTs and SiCP into the grain boundaries of Aluminium matrix and as a result decrease the dislocation defects thus increase and enhance the microstructure and strengthening metallic bond. Outcome of this show that hybrid composite (Al$5 \% \mathrm{CNTs}-10 \% \mathrm{SiC}$ ) exhibits the micro-hardness greater than that of pure-Al.

Shoufa Liu,Yinwei Wang, T. Muthuramalingam, G.Anbuchezhiyan. (2019) [1] Study shows that by using stir casting process fabrication is done of Al7075 Al alloy with reinforcement of boron carbide and $\mathrm{MoS} 2$ as lubricant under varying weight percentage (4\%, $8 \%$ and 12\%). Tribological behavior and mechanical properties like tensile strength, compressive strength and microstructure has been investigated. After analyzing it has been analyzed that there is a uniform distribution of reinforced particle in the metal matrix alloy as dendrites in Al solid solution. The mechanical properties like Compressive strength, tensile strength and hardness of the reinforced composites could be enhance by adding the reinforcement as compared to monolithic alloy. It also improve the coefficient of friction and wear resistance of aluminium hybrid composites has been achieve remaining to addition of solid lubricant (MoS2) next to hard ceramic reinforcement particles boron carbide in the matrix alloy.

Electrical, Wear, Thermal and also cooling rate on mechanical properties are studied previously. And the present study deal with varying the grain size and weight fraction of boron carbide and aluminium on micro and nanometer grain size to check there effect on mechanical properties of material.

\section{EXPERIMENTAL WORK}

\subsection{Raw material}

The materials used in the experiment is Boron carbide with purity $99.95 \%$, density $2.52 \mathrm{~g} / \mathrm{cm}^{3}$ and grain size 50 micron and 50 nanometer which is taken from Parshwamani Metals, Mumbai. Aluminium powder with purity $99.85 \%$, density $2.7 \mathrm{~g} / \mathrm{cm}^{3}$ and grain size of 50 micron and 50 nanometer has been taken from Parshwamani Metals, Mumbai. The chemical composition of pure aluminium and boron carbide are shown below.

TABLE 1: CHEMICAL COMPOSITION OF PURE

\begin{tabular}{|l|l|l|l|l|l|l|l|}
\multicolumn{10}{|c|}{ ALUMINIUM } \\
Element & $\mathbf{F e}$ & $\mathbf{S i}$ & $\mathbf{M g}$ & $\mathbf{M n}$ & $\mathbf{C u}$ & $\mathbf{Z n}$ & Others \\
\hline Wt\% & 0.17 & 0.07 & 0.001 & 0.0008 & 0.005 & 0.003 & Balance \\
\hline
\end{tabular}

TABLE 2: CHEMICAL COMPOSITION OF BORON CARBIDE

\begin{tabular}{|l|l|l|l|l|l|l|}
\hline Element & Fe & Si & B2O3 & C & B & Others \\
\hline Wt\% & 0.2 & 0.1 & 0.5 & 20 & 79 & Balance \\
\hline
\end{tabular}

\subsection{Sample Preparation}

There are two different size sample are prepared one is for tensile test and one is for hardness test.

For hardness test each sample pellet is weight 8 gram and the metal powders are taken according to their weight percentage after compression the size of the pellet formed is $20 \mathrm{~mm}$ diameter and $10 \mathrm{~mm}$ height as shown in figure 1 . The weighing was done in a very precise weighing balance. And for tensile test each sample pellet weight is 20 gram and the metal powders are taken according to their weight percentage after compression the size of the pellet formed is $20 \mathrm{~mm}$ diameter and $25 \mathrm{~mm}$ height as shown in figure 2 . The weighing was done in a very precise weighing balance.

Figure 1: Aluminum and Boron carbide pellets for Hardness test.

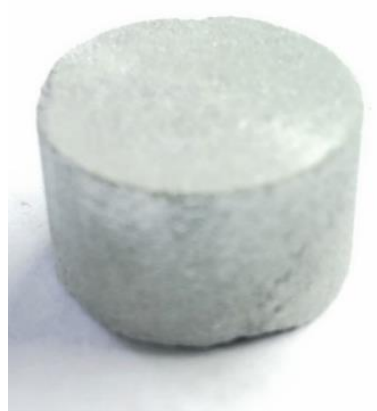

Figure 2: Aluminum and Boron carbide pellets for Tensile test.

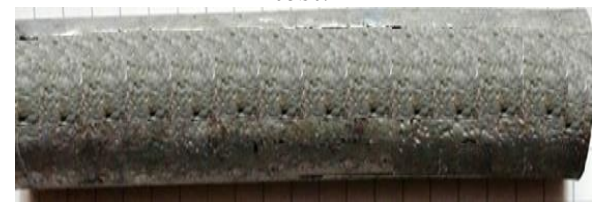

Table 3: Sample Preparation for hardness test

\begin{tabular}{|c|c|c|c|c|c|c|}
\hline $\begin{array}{l}\text { Samp } \\
\text { le }\end{array}$ & \multicolumn{3}{|l}{ Aluminium } & \multicolumn{3}{l|}{ Boron Carbide } \\
\hline & $\begin{array}{l}\text { Perce } \\
\text { ntage }\end{array}$ & $\begin{array}{l}\text { Weight(i } \\
\text { n gram) }\end{array}$ & $\begin{array}{l}\text { Particl } \\
\text { e size }\end{array}$ & $\begin{array}{l}\text { Perce } \\
\text { ntage }\end{array}$ & $\begin{array}{l}\text { Weigh } \\
\text { t(in } \\
\text { gram) }\end{array}$ & $\begin{array}{l}\text { Particle } \\
\text { size }\end{array}$ \\
\hline $\mathbf{1}$ & $97 \%$ & 7.760 & $50 \mu \mathrm{m}$ & $3 \%$ & 0.240 & $50 \mu \mathrm{m}$ \\
\hline $\mathbf{2}$ & $94 \%$ & 7.520 & $50 \mu \mathrm{m}$ & $6 \%$ & 0.480 & $50 \mu \mathrm{m}$ \\
\hline $\mathbf{3}$ & $91 \%$ & 7.280 & $50 \mu \mathrm{m}$ & $9 \%$ & 0.720 & $50 \mu \mathrm{m}$ \\
\hline $\mathbf{4}$ & $88 \%$ & 7.040 & $50 \mu \mathrm{m}$ & $12 \%$ & 0.960 & $50 \mu \mathrm{m}$ \\
\hline $\mathbf{5}$ & $85 \%$ & 6.800 & $50 \mu \mathrm{m}$ & $15 \%$ & 1.200 & $50 \mu \mathrm{m}$ \\
\hline $\mathbf{6}$ & $97 \%$ & 7.760 & $50 \mathrm{~nm}$ & $3 \%$ & 0.240 & $50 \mathrm{~nm}$ \\
\hline $\mathbf{7}$ & $94 \%$ & 7.520 & $50 \mathrm{~nm}$ & $6 \%$ & 0.480 & $50 \mathrm{~nm}$ \\
\hline $\mathbf{8}$ & $91 \%$ & 7.280 & $50 \mathrm{~nm}$ & $9 \%$ & 0.720 & $50 \mathrm{~nm}$ \\
\hline $\mathbf{9}$ & $88 \%$ & 7.040 & $50 \mathrm{~nm}$ & $12 \%$ & 0.960 & $50 \mathrm{~nm}$ \\
\hline $\mathbf{1 0}$ & $85 \%$ & 6.800 & $50 \mathrm{~nm}$ & $15 \%$ & 1.200 & $50 \mathrm{~nm}$ \\
\hline
\end{tabular}

\subsection{Mixing and Compacting}

Boron Powder having grain size 50 micron and $50 \mathrm{~nm}$ with weight percentage $3 \%, 6 \%, 9 \%, 12 \%$ and $15 \%$ is mixed with pure aluminum having grain size 50 micron in stirrer for 6 hours to get proper composition throughout. After that these prepared samples are compact in compacting machine with load 10 tons for 20 seconds so that the green parts are formed.

2.4 Sintering

Sintering is the process in which material is heated below its melting point to strong the bond between the composite materials. In sintering the green part is heated in the Vacuum furnace at $600^{\circ} \mathrm{C}$ for 1 hour. 
Figure 3: Aluminium and boron carbide pellet in sintering furnace.

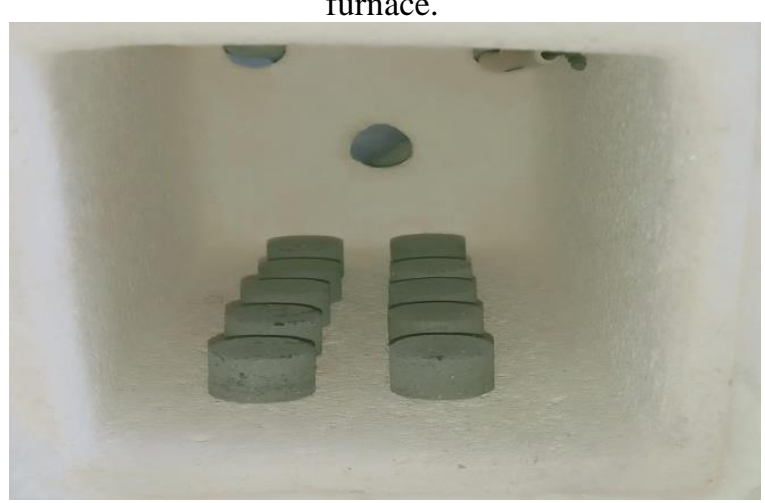

\subsection{Hardness Test}

Hardness is a quality of a material, not a central physical property. It is characterized as resistance to indentation, and it is measured by estimating the perpetual depth of the indentation. Basically, when utilizing a fixed power (load) and a given indenter, the harder the material the smaller the indentation.

And hardness value can be determined through the area or depth of the indentation.[9]

Here we used Rockwell hardness test to determine the hardness of the Aluminum metal matrix composite. First the surface of the specimen is finished by emery paper. Then these polished specimens are kept in Rockwell hardness testing machine. For testing a $100 \mathrm{~kg}$ load is applied by the $0.5 \mathrm{~mm}$ diameter diamond indentor. The same process is repeats for all the samples and average of three reading is considered as hardness value of the sample as shown in Table 4.in which weight percentage of boron carbide increases from $3 \%$ to $15 \%$.

Figure 4: Rockwell hardness tester.

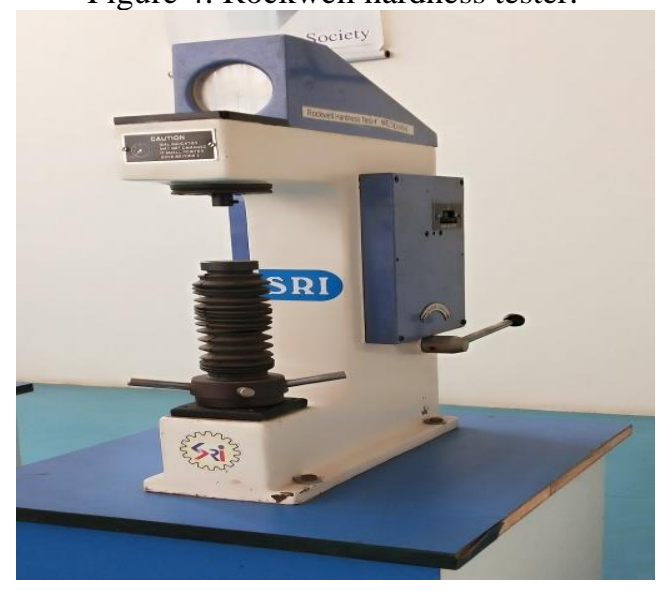

\subsection{Tensile Test}

Tensile testing is a damaging test measure that gives data about the tensile strength, yield quality, and malleability of the metallic material. It gauges the power needed to break a composite or plastic specimen and the degree to which the specimen stretches or prolongs to braking point.[10]

Here we used Universal testing machine to find the ultimate tensile strength of the specimen and ASTM standard was followed.

Figure 5: Universal Testing Machine.

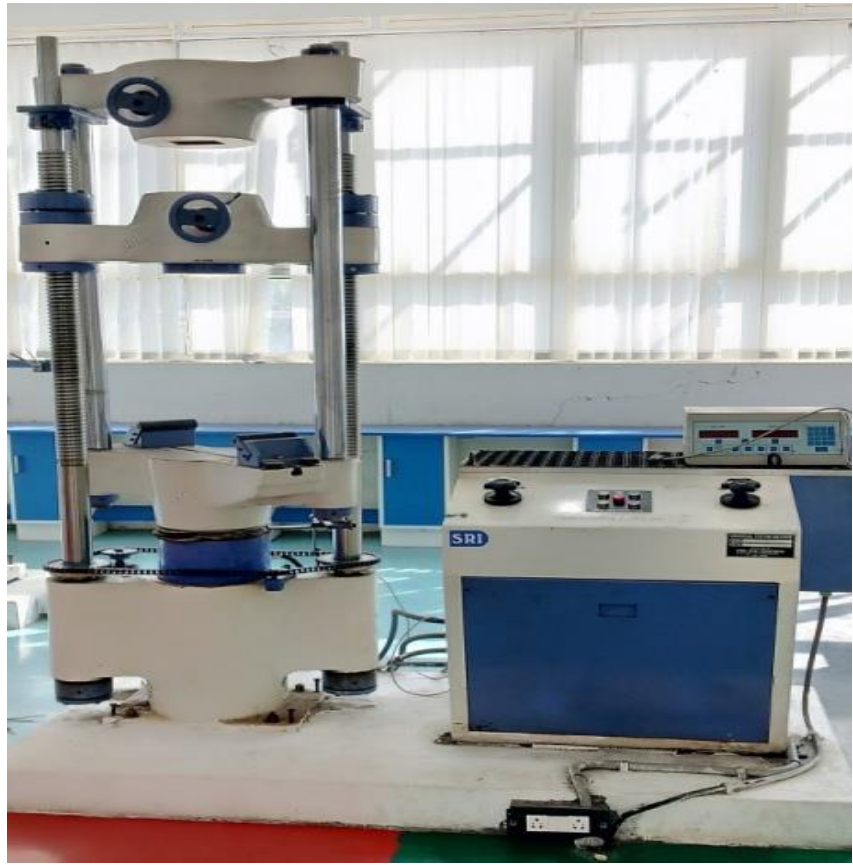

\section{RESULTS}

3.1 Hardness Test

As in table 4 the average hardness value of aluminium metal matrix composite increases with increase in weight percentage of boron carbide greater hardness value with $15 \%$ of boron carbide and lowest with $3 \%$ boron carbide as a reinforcement in aluminium. But the value of hardness of the formed alloy is greater in case of small particle size as compare to large particle size for a given weight as hardness of alloy with $3 \% \mathrm{~B}_{4} \mathrm{C}$ and $97 \% \mathrm{Al}$ nanometer grain size particle is greater as compare to the hardness of $3 \% \mathrm{~B}_{4} \mathrm{C}$ and $97 \% \mathrm{Al}$ micron grain size particle micron similarly for $6 \%, 9 \%, 12 \%$ and $15 \% \mathrm{~B}_{4} \mathrm{C}$ samples.

Table 4: Rockwell Hardness Test

\begin{tabular}{|c|c|c|c|c|c|c|c|}
\hline $\begin{array}{l}\text { S. } \\
\mathbf{N} \\
\text { o. }\end{array}$ & $\begin{array}{l}\text { Alloy } \\
\text { composition } \\
\text { percentage }\end{array}$ & $\begin{array}{l}\text { Alloy particle } \\
\text { size }\end{array}$ & $\begin{array}{l}\text { Loa } \\
\text { d in } \\
\text { Kgf }\end{array}$ & \multicolumn{3}{|c|}{$\begin{array}{l}\text { Rockwell } \\
\text { Hardness } \\
\text { Number }\end{array}$} & $\begin{array}{l}\text { Aver } \\
\text { age } \\
\text { valu }\end{array}$ \\
\hline 1 & $\begin{array}{l}\text { Aluminium- } \\
97 \%, \text { Boron } \\
\text { carbide-3\% }\end{array}$ & \begin{tabular}{l}
\multicolumn{2}{l}{ Aluminium -} \\
$50 \mu \mathrm{m}$ Boron \\
carbide -50 \\
$\mu \mathrm{m}$
\end{tabular} & 100 & 36 & 38 & 36 & $\begin{array}{l}36.6 \\
6\end{array}$ \\
\hline 2 & $\begin{array}{l}\text { Aluminium- } \\
94 \% \text {, Boron } \\
\text { carbide- } 6 \%\end{array}$ & $\begin{array}{l}\text { Aluminium - } \\
50 \mu \mathrm{m} \text { Boron } \\
\text { carbide }-50 \\
\mu \mathrm{m}\end{array}$ & 100 & 38 & 40 & 41 & $\begin{array}{l}39.6 \\
6\end{array}$ \\
\hline 3 & $\begin{array}{l}\text { Aluminium- } \\
91 \% \text {, Boron } \\
\text { carbide-9\% }\end{array}$ & $\begin{array}{l}\text { Aluminium - } \\
50 \mu \mathrm{m} \text { Boron } \\
\text { carbide }-50 \\
\mu \mathrm{m}\end{array}$ & 100 & 40 & 42 & 43 & $\begin{array}{l}41.6 \\
6\end{array}$ \\
\hline 4 & $\begin{array}{l}\text { Aluminium- } \\
88 \% \text {, Boron } \\
\text { carbide- } 12 \%\end{array}$ & $\begin{array}{l}\text { Aluminium - } \\
50 \mu \mathrm{m} \text { Boron } \\
\text { carbide }-50 \\
\mu \mathrm{m}\end{array}$ & 100 & 41 & 44 & 46 & $\begin{array}{l}43.6 \\
6\end{array}$ \\
\hline 5 & $\begin{array}{l}\text { Aluminium- } \\
85 \% \text {, Boron } \\
\text { carbide- } 15 \%\end{array}$ & $\begin{array}{l}\text { Aluminium - } \\
50 \mu \mathrm{m} \text { Boron } \\
\text { carbide }-50 \\
\mu \mathrm{m}\end{array}$ & 100 & 43 & 47 & 48 & 46 \\
\hline 6 & $\begin{array}{l}\text { Aluminium- } \\
97 \% \text {, Boron } \\
\text { carbide-3\% }\end{array}$ & $\begin{array}{l}\text { Aluminium - } \\
50 \mathrm{~nm} \text { Boron } \\
\text { carbide }-50 \\
\mathrm{~nm}\end{array}$ & 100 & 39 & 40 & 41 & 40 \\
\hline
\end{tabular}




\begin{tabular}{|l|l|l|l|l|l|l|l|}
\hline $\mathbf{7}$ & $\begin{array}{l}\text { Aluminium- } \\
94 \%, \text { Boron } \\
\text { carbide-6\% }\end{array}$ & $\begin{array}{l}\text { Aluminium - } \\
50 \text { nm Boron } \\
\text { carbide - 50 } \\
\text { nm }\end{array}$ & 100 & 41 & 41 & 43 & $\begin{array}{l}41.6 \\
6\end{array}$ \\
\hline $\mathbf{8}$ & $\begin{array}{l}\text { Aluminium- } \\
91 \%, \text { Boron } \\
\text { carbide-9\% }\end{array}$ & $\begin{array}{l}\text { Aluminium - } \\
50 \text { nm Boron } \\
\text { carbide - 50 } \\
\text { nm }\end{array}$ & 100 & 42 & 44 & 45 & 43.6 \\
6
\end{tabular}

\subsection{Tensile Test}

As in table 5 the value Ultimate tensile strength of aluminium metal matrix composite increments with increment in weight level of boron carbide higher Ultimate tensile strength value esteem with $15 \%$ of boron carbide and most minimal with $3 \%$ boron carbide as a reinforcement in aluminium. But the value of Ultimate tensile strength of the formed alloy is greater in case of small particle size as compare to large particle size for a given weight as ultimate tensile strength of alloy with $3 \%$ $\mathrm{B}_{4} \mathrm{C}$ and $97 \% \mathrm{Al}$ nanometer grain size particle is greater as compare to the ultimate tensile strength of $3 \% \mathrm{~B}_{4} \mathrm{C}$ and $97 \% \mathrm{Al}$ micron grain size particle micron similarly for $6 \%$, $9 \%, 12 \%$ and $15 \% \mathrm{~B}_{4} \mathrm{C}$ samples.

Table 5: Tensile Test

\begin{tabular}{|l|l|l|l|}
\hline S.No. & $\begin{array}{l}\text { Alloy composition } \\
\text { percentage }\end{array}$ & Alloy particle size & UTS (MPa) \\
\hline $\mathbf{1}$ & $\mathrm{Al}-97 \%, \mathrm{~B}_{4} \mathrm{C}-3 \%$ & $\begin{array}{l}\mathrm{Al}-50 \mu \mathrm{m} \\
\mathrm{B} 4 \mathrm{C}-50 \mu \mathrm{m}\end{array}$ & 110 \\
\hline $\mathbf{2}$ & $\mathrm{Al}-94 \%, \mathrm{~B}_{4} \mathrm{C}-6 \%$ & $\begin{array}{l}\mathrm{Al}-50 \mu \mathrm{m} \\
\mathrm{B} 4 \mathrm{C}-50 \mu \mathrm{m}\end{array}$ & 115 \\
\hline $\mathbf{3}$ & $\mathrm{Al}-91 \%, \mathrm{~B}_{4} \mathrm{C}-9 \%$ & $\begin{array}{l}\mathrm{Al}-50 \mu \mathrm{m} \\
\mathrm{B} 4 \mathrm{C}-50 \mu \mathrm{m}\end{array}$ & 124 \\
\hline $\mathbf{4}$ & $\mathrm{Al}-88 \%, \mathrm{~B}_{4} \mathrm{C}-12 \%$ & $\begin{array}{l}\mathrm{Al}-50 \mu \mathrm{m} \\
\mathrm{B} 4 \mathrm{C}-50 \mu \mathrm{m}\end{array}$ & 130 \\
\hline $\mathbf{5}$ & $\mathrm{Al}-85 \%, \mathrm{~B}_{4} \mathrm{C}-15 \%$ & $\begin{array}{l}\mathrm{Al}-50 \mu \mathrm{m} \\
\mathrm{B} 4 \mathrm{C}-50 \mu \mathrm{m}\end{array}$ & 137 \\
\hline $\mathbf{6}$ & $\mathrm{Al}-97 \%, \mathrm{~B}_{4} \mathrm{C}-3 \%$ & $\begin{array}{l}\mathrm{Al}-50 \mathrm{~nm} \\
\mathrm{~B} 4 \mathrm{C}-50 \mathrm{~nm}\end{array}$ & 114 \\
\hline $\mathbf{7}$ & $\mathrm{Al}-94 \%, \mathrm{~B}_{4} \mathrm{C}-6 \%$ & $\begin{array}{l}\mathrm{Al}-50 \mathrm{~nm} \\
\mathrm{~B} 4 \mathrm{C}-50 \mathrm{~nm}\end{array}$ & 120 \\
\hline $\mathbf{8}$ & $\mathrm{Al}-91 \%, \mathrm{~B}_{4} \mathrm{C}-9 \%$ & $\begin{array}{l}\mathrm{Al}-50 \mathrm{~nm} \\
\mathrm{~B} 4 \mathrm{C}-50 \mathrm{~nm}\end{array}$ & 128 \\
\hline $\mathbf{9}$ & $\mathrm{Al}-88 \%, \mathrm{~B}_{4} \mathrm{C}-12 \%$ & $\begin{array}{l}\mathrm{Al}-50 \mathrm{~nm} \\
\mathrm{~B} 4 \mathrm{C}-50 \mathrm{~nm}\end{array}$ & 134 \\
\hline $\mathbf{1 0}$ & $\mathrm{Al}-85 \%, \mathrm{~B}_{4} \mathrm{C}-15 \%$ & $\begin{array}{l}\mathrm{Al}-50 \mathrm{~nm} \\
\mathrm{~B} 4 \mathrm{C}-50 \mathrm{~nm}\end{array}$ & 139 \\
\hline
\end{tabular}

Figure 6 represent the bar chart between the micron size $\mathrm{B}_{4} \mathrm{C}$ particle weight percentage and their effect on ultimate tensile strength. And Figure 7 represents the bar chart between the nanometer size $\mathrm{B}_{4} \mathrm{C}$ particle weight percentage and their effect on ultimate tensile strength
.Figure 6: Bar chart of micron size $\mathrm{B}_{4} \mathrm{C}$ particle wt\% with Ultimate tensile stress.

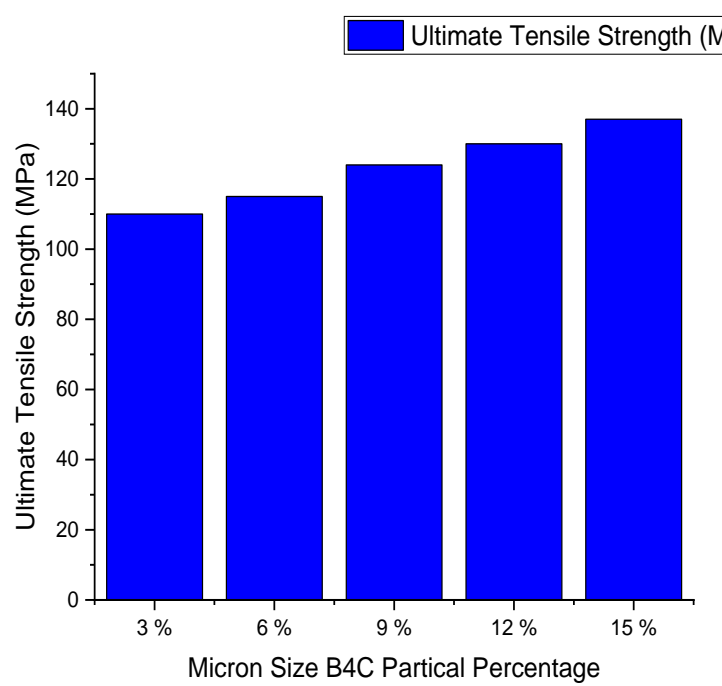

Figure 7: Bar chart of nanometer size $\mathrm{B}_{4} \mathrm{C}$ particle wt $\%$ with Ultimate tensile stress.

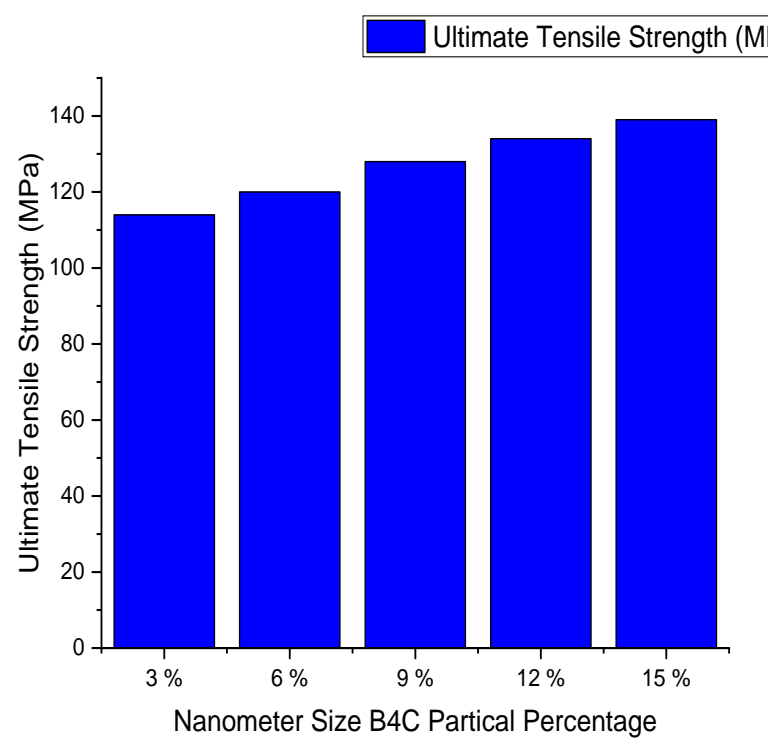

\section{CONCLUSION}

Aluminium metal matrix composite with Boron carbide as reinforcement. The tensile and hardness value are increased with increase the weight percentage of boron carbide from $3 \%$ to $15 \%$. Furthermore, the estimation of hardness and ultimate tensile strength with grain size of both aluminum and boron carbide in nanometer is consistently higher when contrasted with hardness and ultimate tensile strength with grain size of both aluminum and boron carbide in micron having same weight and extent of aluminum and boron carbide in the two cases. 


\section{REFRENCES}

[1] S. Liu, Y. Wang, T. Muthuramalingam, and G. Anbuchezhiyan, "Effect of B4C and MOS2 reinforcement on micro structure and wear properties of aluminum hybrid composite for automotive applications," Compos. Part B Eng., vol. 176, no. August, p. 107329, 2019, doi: 10.1016/j.compositesb.2019.107329.

[2] N. D. Chinta, N. Selvaraj, and V. Mahesh, "Mechanical characterization of aluminium - Red mud metal matrix composites," Mater. Today Proc., vol. 5, no. 13, pp. 2691126917, 2018, doi: 10.1016/j.matpr.2018.08.178.

[3] K. T. Akhil, J. Varghese, A. Raphel, K. Vinoj, and F. K. Francis, "To Study the Cooling Rate and Influence of Boron Carbide on Mechanical Properties of Aluminium LM13 Matrix B4C Reinforced Composites," Mater. Today Proc., vol. 4, no. 8, pp. 7202-7207, 2017, doi: 10.1016/j.matpr.2017.07.047.

[4] M. Jayaram, "Microstructure Analysis of Aluminium- Boron Carbide With Addition of Flyash By Using Powder Metallurgy Technique,” Int. Res. J. Latest Trends Eng. Technol., vol. 2, no. 2, pp. 44-49, 2015.

[5] M. Trimurthulu, "Evaluation of Mechanical Properties of Aluminium- Boron Carbide Composites," vol. 3, no. 2, pp. 188 193, 2018.

[6] D. O. F. Philosophy, "Synthesis And Characterization Of Nanocrystalline High Entropy Alloys By Parents," Technology, no. December, pp. 1-10, 2008.

[7] C. Prakash et al., "Fabrication of aluminium carbon nano tube silicon carbide particles based hybrid nano-composite by spark plasma sintering," Mater. Today Proc., vol. 21, no. xxxx, pp. 1637-1642, 2020, doi: 10.1016/j.matpr.2019.11.273.
[8] K. K. Saravanan and S. Mahendran, "Aluminium 6082-boron carbide composite materials preparation and investigate mechanical-electrical properties with CNC turning," Mater. Today Proc., vol. 21, no. xxxx, pp. 93-97, 2020, doi: 10.1016/j.matpr.2019.05.368.

[9] E. Alfredo Campo, "5 Physical Properties of Polymeric Materials," Sel. Polym. Mater., pp. 175-203, 2008, doi: 10.1016/B978-0-8155-1551-7.50007-3

[10] N. Saba, M. Jawaid, and M. T. H. Sultan, An overview of mechanical and physical testing of composite materials. Elsevier Ltd, 2018. 